\title{
RANCANG BANGUN APLIKASI EDUKASI HARDWARE KOMPUTER BERBASIS TEKNOLOGI AUGMENTED REALITY MENGGUNAKAN ANDROID
}

\author{
ANDRI WAHYU SAPUTRA \\ ADHI SUSANO \\ PUJI ASTUTI \\ Program Studi Informatika \\ Fakultas Teknik dan Ilmu Komputer \\ Universitas Indraprasta PGRI \\ Email: Andry.220f@gmail.com, adhi.susano@gmail.com
}

\begin{abstract}
Abstrak. Dalam mempelajari dan memvisualisasikan perangkat komputer pelajar maupun mahasiswa cenderung mengalami kesulitan ketika ingin mempelajari dan menghafal unit unit komputer. Penelitian ini bertujuan untuk membuat suatu aplikasi pembelajaran tentang hardware komputer dengan memanfaatkan perkembangan teknologi smartphone berbasis android menggunakan teknologi augmented reality. Metode pengembangan yang digunakan untuk membangun aplikasi ini adalah metode waterfall. Pembuatan aplikasi ini menggunakan bahasa C\# dan software game engine unity 3D. Aplikasi ini menerapkan vuforia sebagai SDK untuk menciptakan augmented reality yang berjalan pada OS android dan menggunakan virtual button yang terletak pada marker. Aplikasi ini memberikan informasi dan menampilkan objek 3D tentang hardware komputer, khusus untuk unit pemprosesan yaitu proccessor, motherboard, ram, hardisk dan vga. Subjek penelitian yang dipilih adalah pelajar dan mahasiswa yang telah mempelajari komponen hardware komputer. Hal ini ditentukan untuk mengetahui kesulitan yang dihadapai pelajar maupun mahasiswa dalam mempelajari materi hardware komputer.

Kata Kunci: Android, Augmented Reality, Komputer, Waterfall, Unity
\end{abstract}

Abstract. In studying and visualizing computer devices students and students tend to experience difficulties when they want to learn and memorize computer units. This study aims to create a learning application about computer hardware by utilizing the development of Android-based smartphone technology using augmented reality technology. The development method used to build this application is the waterfall method. Making this application uses $C$ \# language and unity $3 D$ game engine software. This application applies vuforia as SDK to create an augmented reality that runs on the Android OS and uses a virtual button located in the marker. This application provides information and displays $3 D$ objects about computer hardware, specifically for processing units, namely processor, motherboard, RAM, hard drive and VGA. The chosen research subjects were students and students who had studied computer hardware components. This is determined to find out the difficulties faced by students and students in exploring the material of computer hardware.

Keyword: Android, Augmented Reality, Computer, Waterfall, Unity

\section{PENDAHULUAN}

Pada era globalisasi, teknologi merupakan suatu alat yang digunakan untuk mempermudah kehidupan manusia. Perkembangan teknologi informasi dan komunikasi sendiri telah berkembang sangat pesat di segala bidang. Menurut Sutarbi (2013:10) Teknologi Informasi meliputi segala hal yang berkaitan dengan proses, penggunaan sebagai alat bantu, memanipulasi, dan pengelolahan informasi sedangkan Teknologi Komunikasi adalah segala sesuatu yg berkaitan dengan penggunaan alat bantu unutk memprosess dan mentransfer data dari perangkat yang satu ke yang lain. Maka teknologi informasi dan komunikasi merupakan 
suatu alat bantu yang mengolah, memproses, dan menyampaikan suatu informasi dan komputer merupakan salah satu alat yang erat kaitannya dangan perkembangan teknologi informasi dan komunikasi.

Komputer adalah suatu alat elektronik yg mampu melakukan beberapa tugas, yaitu menerima input, memproses input sesuai dengan instruksi yang diberikan, menyimpan perintah-perintah dan hasil pengolahannya, serta menyediakan output dalam bentuk informasi (Dhanta, 2009). Pada zaman modern ini komputer memiliki banyak manfaat dalam kehidupan manusia sebagai media komunikasi, pengolahan data, sarana pendidikan dan sarana hiburan, maka dari itu setiap orang dituntut harus dapat mengoperasikan komputer. Saat ini masyarakat sudah menggunakan komputer untuk membantu pekerjaannya sehari-hari, baik menggunakan komputer desktop maupun menggunakan laptop. Komputer sendiri sangat penting dalam bidang pendidikan terutama dalam media pembelajaran.

Permasalahan yang ada saat ini adalah masyarakat khusunya pelajar dan mahasiswa yang telah menggunakan teknologi komputer ini tidak mengetahui atau mengenal hardware atau komponen penyusun dari komputer tersebut yang menyebabkan mereka tidak dapat melakukan troubleshooting jika terjadi kerusakan pada hardware komputer maupun laptop. untuk mempelajari hardware komputer dapat dengan menggunakan media-media seperti buku dan internet, tetapi cara ini dianggap kurang efektif, karena untuk mempelajari hardware komputer diperlukan suatu alat peraga. Seperti halnya yang dilakukan di SMK (Sekolah Menengah Kejuruan), mereka menggunakan hardware komputer secara langsung sebagai alat peraga dalam pembelajaran mereka. Tetapi untuk melakukan hal itu tidak mudah, kita harus memiliki komputer atau laptop sendiri yang harus siap untuk menjadi bahan praktek yang sudah pasti memerlukan biaya yang tidak sedikit.

\section{Landasan Teori \\ Pengertian Komputer}

Komputer (computer) berasal dari kata compute yang berarti menhitung. Proses dalam komputer merupakan operasi hitungan matematika. Komputer merupanakan mesin berhitung elektronik yang dapat diprogram. Menurut Hasnul Arifin (2009:7) komputer adalah peralatan elektronika yang menerima masukan data, menghitung olah data dan memberikan hasil keluaran dalam bentuk informasi baik berupa teks, gambar, suara, maupun video.

Secara modern komputer dapat didefinisikan sebagai suatu suatu alat elektronik yg mampu melakukan beberapa tugas, yaitu menerima input, memproses input sesuai dengan instruksi yang diberikan, menyimpan perintah-perintah dan hasil pengolahannya, serta menyediakan output dalam bentuk informasi.

\section{Augmented Reality}

Augmented reality merupakan jembatan antara dunia nyata dan dunia maya secara realtime (Sagita \& Amalia, 2014). Menurut penjelasan Haller, Billinghurst \& Thomas (2007:7), riset Augmented Reality bertujuan untuk mengembangkan teknologi yang memungkinkan penggabungan secara real-time terhadap digital content yang dibuat oleh komputer dengan dunia nyata. Augmented Reality memungkinkan pengguna melihat objek maya dua dimensi atau tiga dimensi yang divisualisasikan terhadap dunia nyata.

Augmented Reality (AR) merupakan teknologi yang menggabungkan benda maya dua dimensi dan atau tiga dimensi ke dalam sebuah lingkungan nyata lalu memproyeksikan benda-benda maya tersebut dalam waktu nyata. Tidak seperti realitas maya yang sepenuhnya menggantikan kenyataan, namun Augmented Reality hanya menambahkan atau melengkapi kenyataan. Bendabenda maya menampilkan informasi yang tidak dapat diterima oleh pengguna dengan panca indra. Hal ini membuat Augmented Reality sesuai sebagai alat untuk membantu persepsi dan 
interaksi penggunanya dengan dunia nyata melalui medianya. Informasi yang ditampilkan oleh benda maya membantu pengguna melaksanakan kegiatan - kegiatan dalam dunia nyata.

\section{Pengenalan Android}

Menurut Sherief Salbino (2015: 7), Android merupakan sistem berbasis linux yang bersifat open source dan dirancang untuk perangkat seluler layar sentuh seperti smartphone dan komputer tablet. Android dikembangkan oleh Android, Inc., dengan dukungan finansial dari google yang kemudian dibeli pada tahun 2005. Android dirilis secara resmi pada tahun 2007, bersamaan dengan didirikannya open handset alliance.

Dengan sifat open source yang dimiliki android, memungkinkan para pengembang aplikasi untuk berlomba-lomba membuat aplikasi android baik itu aplikasi bisnis, keamanan, utilities, maupun aplikasi games. Hal ini yang menybabkan masyarakat memilih android sebagai sistem operasi yang digunakan untuk smartphone mereka. Menurut data dari IDC World Wide Mobile Phone Tracker, android berada pada posisi pertama dalam survei penggunaan os smartphone.

Table 1. Survei OS Smartphone

Sumber: https://www.idc.com

\begin{tabular}{c|cccc}
\hline Period & Android & iOS & Windows Phone & Others \\
\hline 2015Q4 & $79.6 \%$ & $18.7 \%$ & $1.2 \%$ & $0.5 \%$ \\
2016Q1 & $83.5 \%$ & $15.4 \%$ & $0.8 \%$ & $0.4 \%$ \\
2016Q2 & $87.6 \%$ & $11.7 \%$ & $0.4 \%$ & $0.3 \%$ \\
2016Q3 & $86.8 \%$ & $12.5 \%$ & $0.3 \%$ & $0.4 \%$ \\
\hline
\end{tabular}

\section{METODE}

Perancangan aplikasi ini menggunakan model air terjun (waterfal). Menurut Arisandy Ambarita \& Muharto(2016:104), metode waterfall muncul pertama kali pada tahun 1970 sehingga sering dianggap kuno, tetapi merupakan model yang paling banyak digunakan dalam sofware engineering (SE). Metode ini melakukan pendekatan secara sistematis dan urut mulai dari level kebutuhan sistem lalu menuju tahap analisis, desain, coding, testing/ vertification dan maintenance. Disebut dengan waterfall karena tahap demi tahap yang dilalui harus menunggu tahap sebelumnya dan berjalan berurutan.

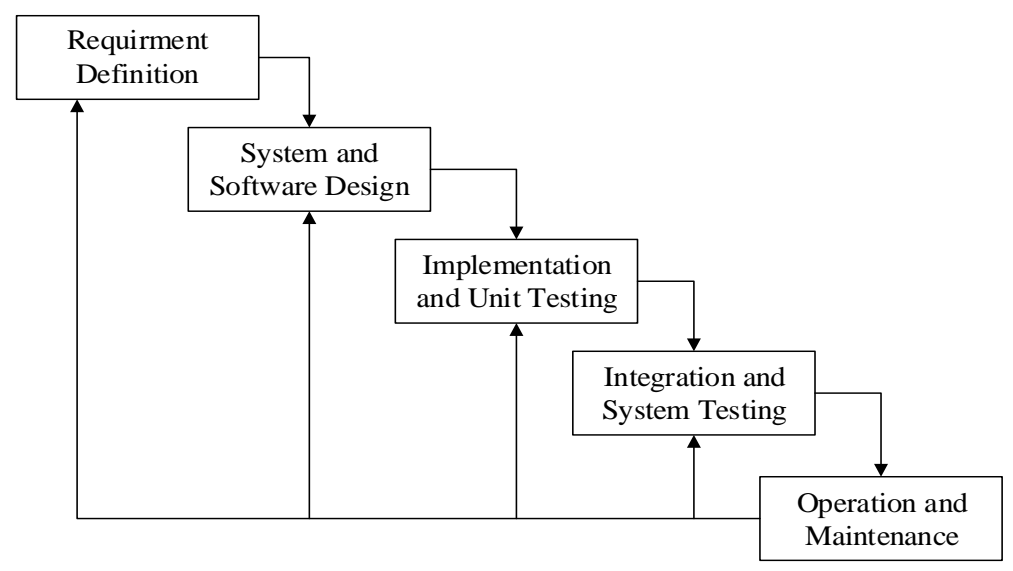

Gambar 1. Metode Waterfall

1) Requirment Definition 
Mengumpulkan apa saja yang dibutuhkan secara lengkap untuk kemudian dianalisis guna mendefinisikan kebutuhan yang harus dipenuhi oleh program. Fase ini harus dikerjakan secara lengkap untuk bisa menghasilkan desain yang lebih lengkap.

2) System and software design

Setelah apa yang dibutuhkan selesai dikumpulkan dan sudah lengkap maka desain kemudian dikerjakan.

3) Implementation and unit testing

Desain program diterjemahkan kedalam kode - kode dengan menggunakan bahasa pemrograman yang telah ditentukan. Program yang telah dibangun langsung diuji secara unit, apakah prorgam sudah berjalan dengan baik.

4) Integration and system testing

Penyatuan unti-unit program untuk kemudian diuji secara keseluruhan(system testing).

5) Operation and maintenance

Mengoperasikan program dilingkungannya dan melakukan pemeliharaan, seperti penyesuaian atau perubahan untuk adaptasi dengan situasi yang benar.

\section{Perancangan Perangkat Lunak}

\section{Algoritma Penyelesaian Masalah dengan Flowchart}

Flowchart merupakan gambaran secara grafik dari langkah-langkah dan urutan-urutan prosedur dari suatu program yang dibuat. Flowchart menggambarkan urutan logika dari suatu prosedur pemecahan masalah, sehingga flowchart merupakan langkah-langkah penyelesaian masalah yang dituliskan dalam simbol-simbol tertentu. Alur program (flowchart) aplikasi edukasi hardware komputer sebagai berikut:

\section{Flowchart Menu Splashscreen}

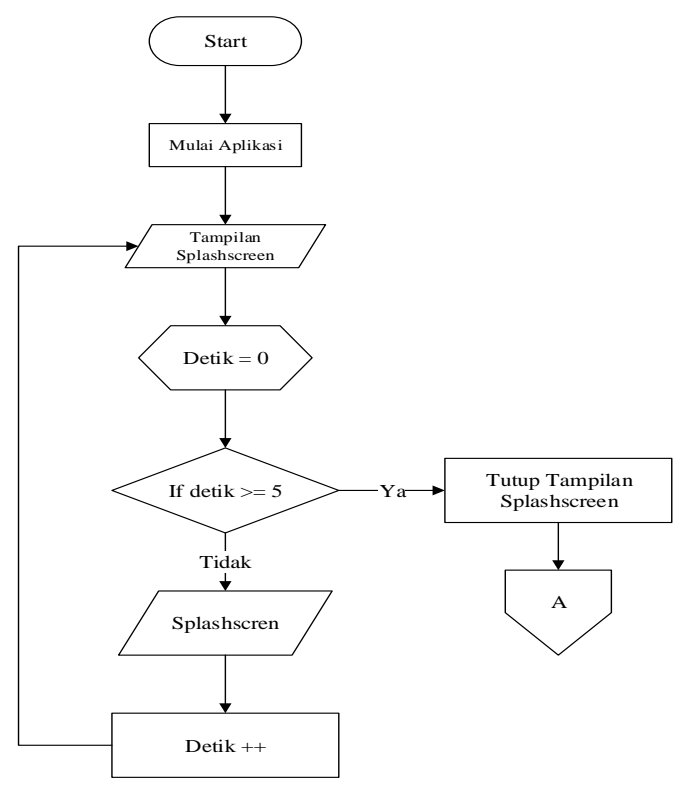

Gambar 2. Flowchart splashscreen

\section{Flowchart Menu Utama}

Menu utama terdiri dari tombol menu start, tombol menu marker, tombol menu petunjuk, dan tombol menu keluar. 


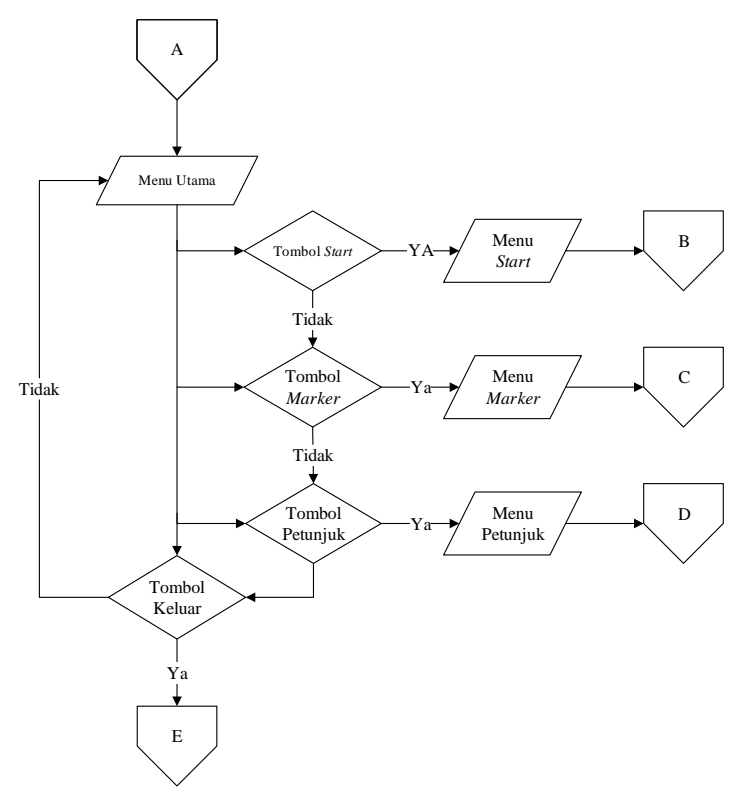

Gambar 3. Flowchart Menu Utama

\section{Flowchart Menu Start}

Menu start adalah menu untuk memulai aplikasi augmented reality, maka saat menu start dipilih akan langsung masuk kedalam mode kamera untuk memindai marker.

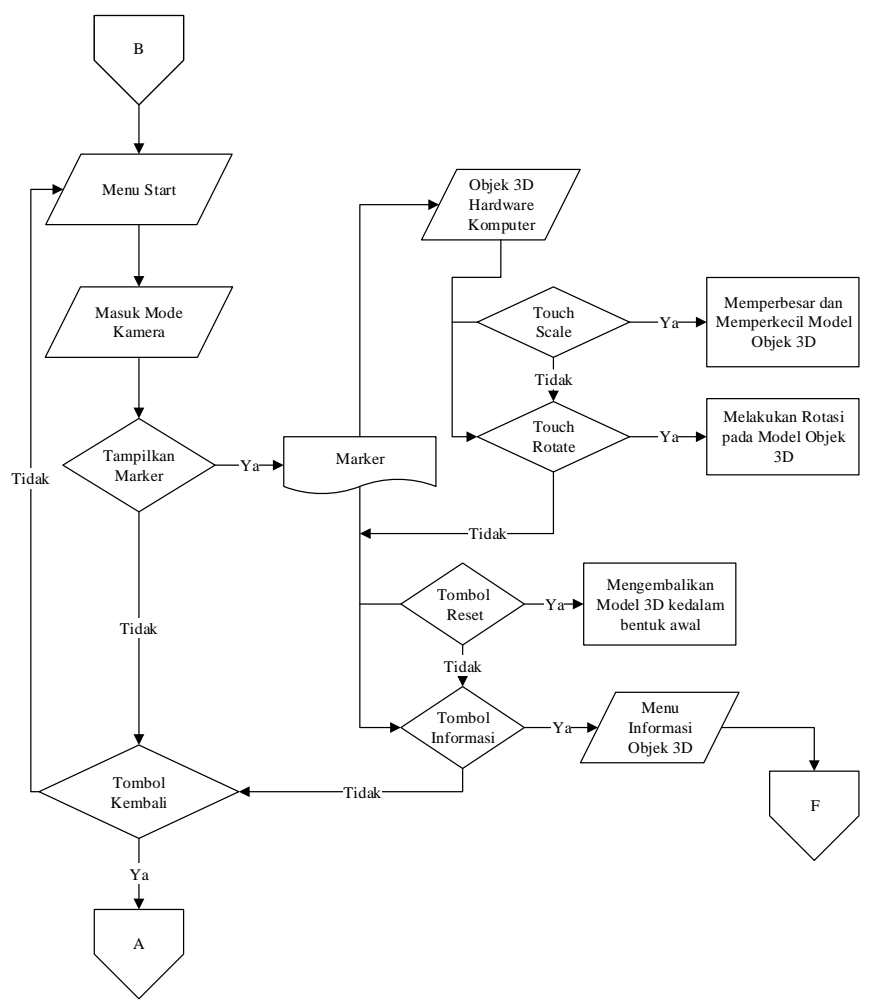

Gambar 4. Flowchart Menu Start 


\section{Flowchart Menu Informasi}

Menu informasi adalah menu yang memberikan deskripsi mengenai objek 3D yang ditampilakan dari salah satu marker.

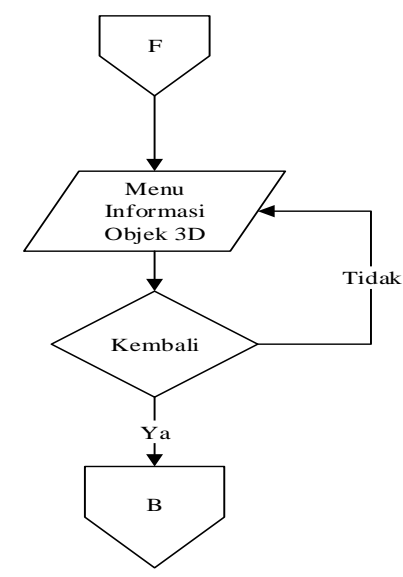

Gambar 5. Flowchart Menu Start

\section{Flowchart Menu Marker}

Didalam menu marker terdapat 5 macam gambar yang digunakan sebagai marker untuk augmented reality. Marker merupakan penanda yang mewakili katalog dimana aplikasi akan mengidentifikasi marker dan kemudian menampilkan onjek tiga dimensi diatas marker. Marker dibuat menggunakan aplikasi Adobe Photoshop CS3 (Paliling, 2017). Terdapat tombol download pada setiap gambar yang berguna untuk mendownload setiap gambar.

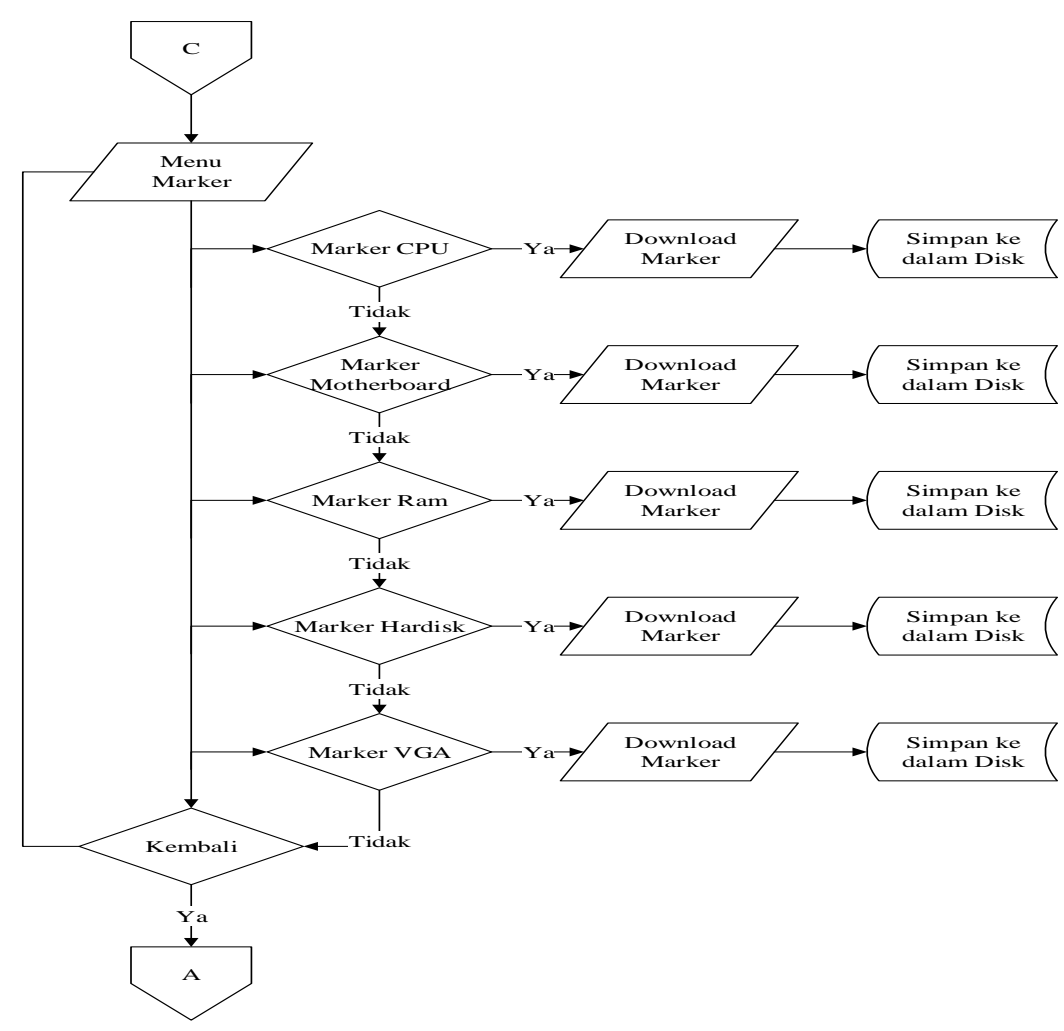

Gambar 6. Flowchart Menu Marker 


\section{Flowchart Menu Petunjuk}

Menu pentunjuk adalah menu yang menunjukan langkah - langkah penggunaan aplikasi.

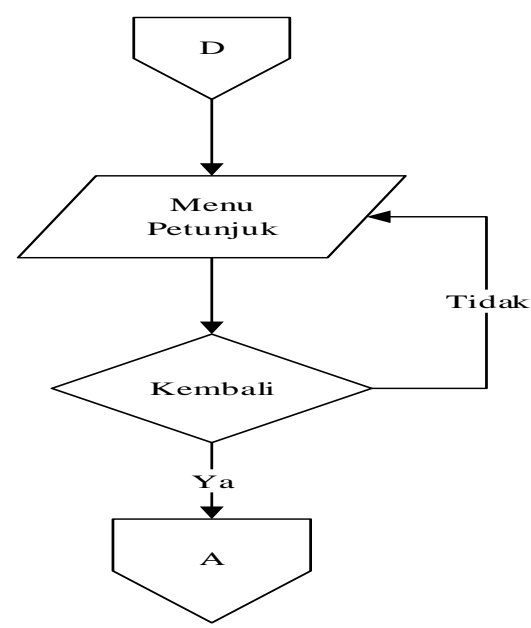

Gambar 7. Flowchart Menu Petunjuk

\section{Flowchart Menu Keluar}

Menu keluar adalah menu terakhir dalam menu utama yang digunakan sebagai menu untuk mengakhiri aplikasi.

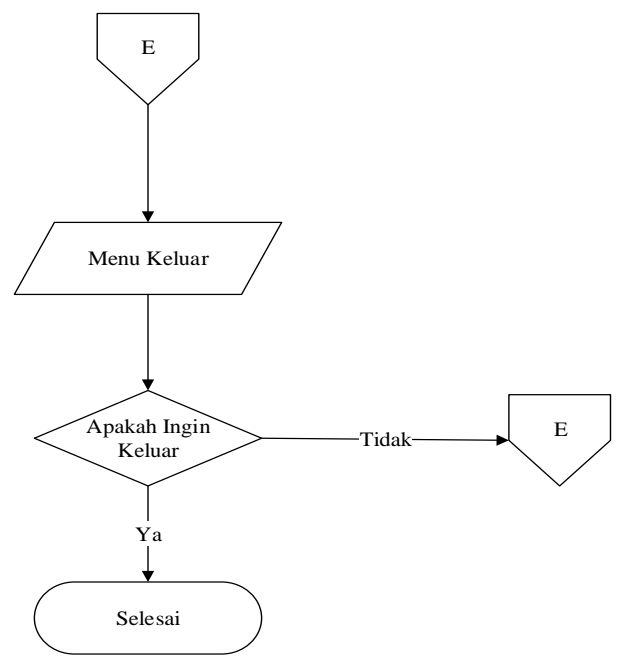

Gambar 8. Flowchart Menu Keluar

\section{HASIL DAN PEMBAHASAN}

\section{Uji Coba dengan Contoh Data}

Setelah aplikasi edukasi hardware komputer berhasil dibuat, maka tahap selanjutnya adalah melakukan uji coba aplikasi terhadap smartphone android untuk memastikan aplikasi berjalan dengan baik.Berikut struktur navigasi dari aplikasi edukasi hardware komputer : 


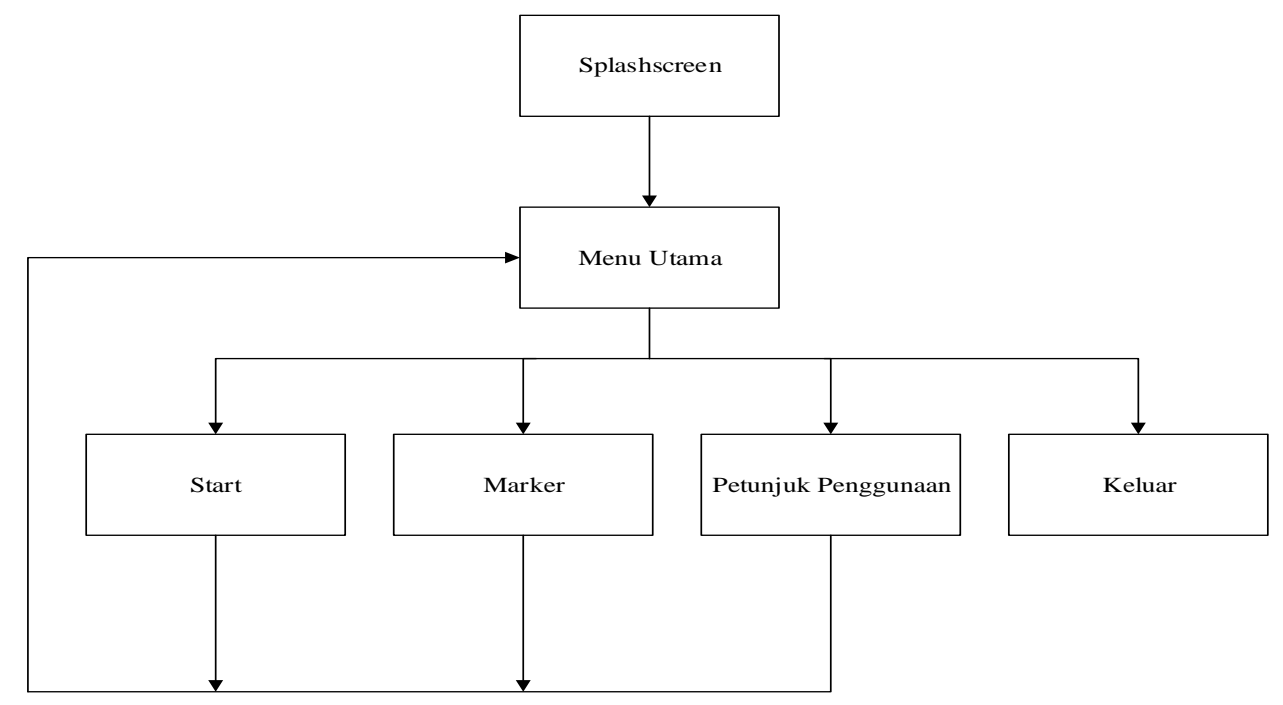

Gambar 9. Struktur Navigasi

Uji program bertujuan untuk mengetahui aplikasi dapat berjalan baik pada versi yang berbeda dan memiliki tampilan yang cocok terhadap tipe layar yang berbeda-beda. Dibawah ini adalah tampilan program saat penulis mencoba pada smartphone android sony xperia M4 aqua versi 6.0 (marshmallow).

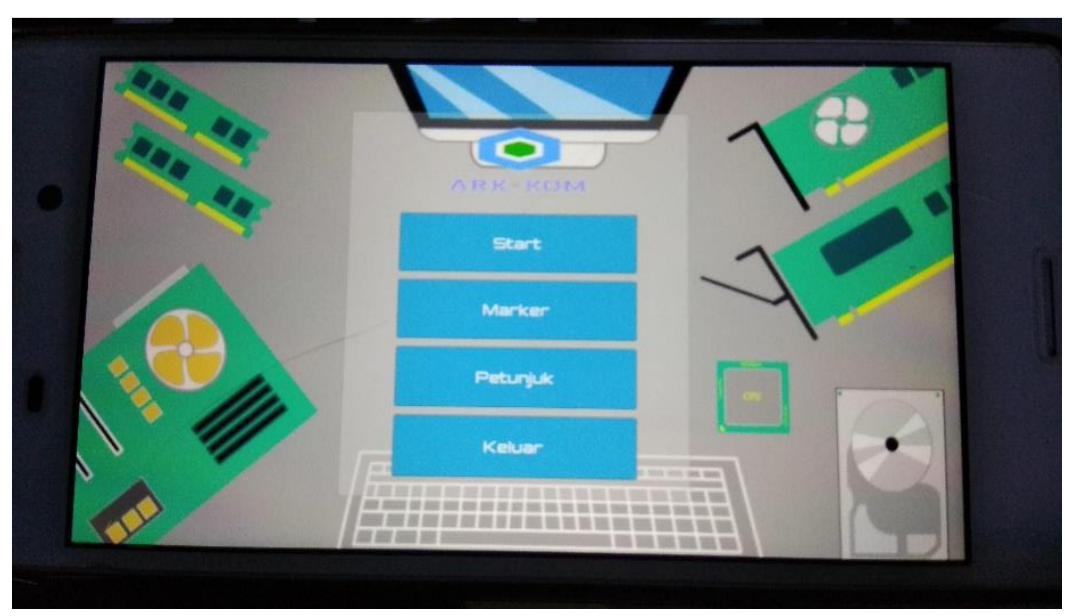

Gambar 10. Tampilan Menu Utama

Gambar 10 adalah tampilan menu utama yang memiliki empat tombol yaitu tombol start, tombol marker, tombol petunjuk dan tombol keluar. 


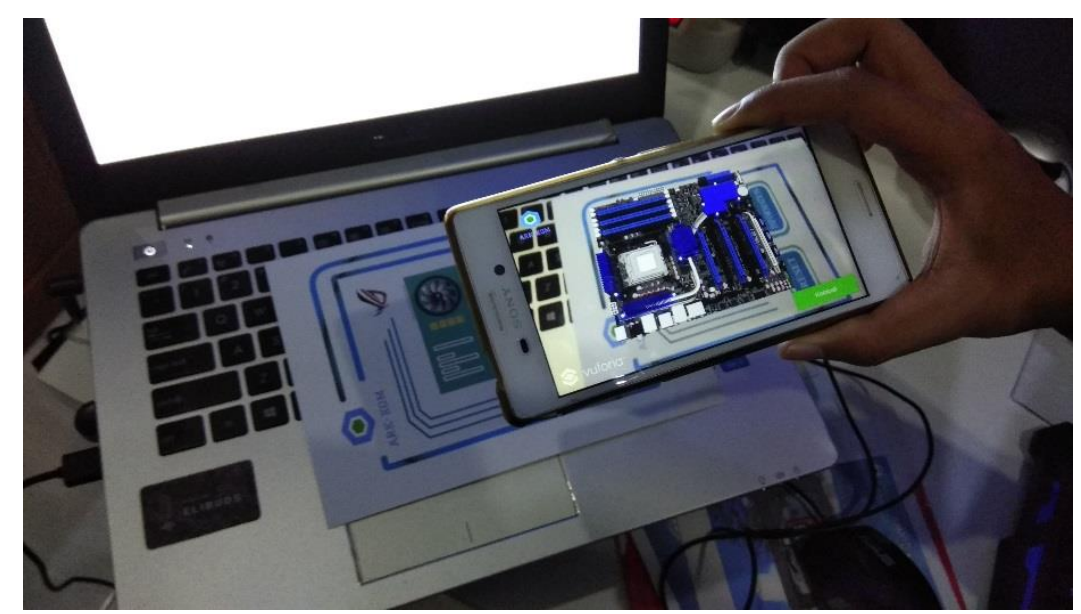

Gambar 11. Tampilan Menu Start

Menu start adalah tampilan mode kamera augmented reality, berdasarkan gambar 11 smartphone penulis berada dalam menu start dan mengarahkan kamera ke marker dan memunculkan objek 3D.

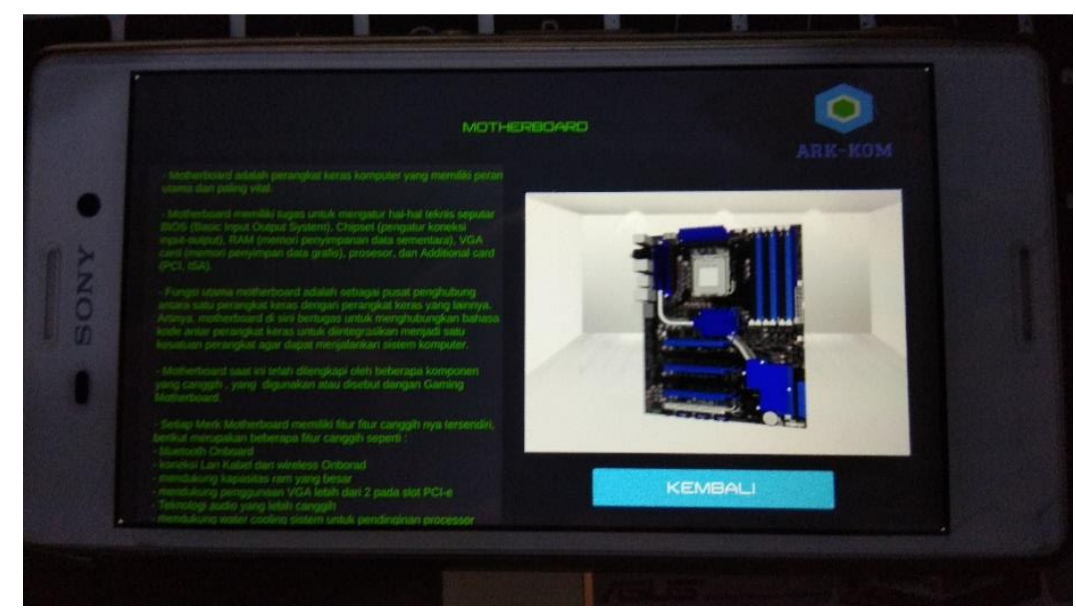

Gambar 12. Tampilan Menu Informasi

Pada gambar 12 dapat terlihat bahwa tampilan ini menunjukan informasi mengenai objek 3D sesuai dengan marker yang di tampilkan. Dengan menekan virtual button yang terletak pada marker.

Terdapat juga beberapa hasil uji coba yang dilakukan dengan menggunakan smartphone android merk lainnya, dibawah ini adalah table hasil data percobaan aplikasi augmented reality edukasi hardware komputer berbasis android :

Table 2. Hasil uji coba prorgam dengan contoh data

\begin{tabular}{llllllll}
\hline No & Merk & Type & $\begin{array}{l}\text { Versi } \\
\text { OS }\end{array}$ & Instalasi & $\begin{array}{l}\text { Kualitas } \\
\text { Gambar }\end{array}$ & $\begin{array}{l}\text { Tampilan } \\
\text { Layout }\end{array}$ & Error \\
\hline 1 & Sony & M4 Aqua & 6.0 & Berhasil & Baik & Baik & Tidak ada \\
2 & Xiaomi & Redmi Note & 6.0 & Berhasil & Sangat & Sangat & Tidak ada \\
\hline
\end{tabular}




\begin{tabular}{|c|c|c|c|c|c|c|c|}
\hline & & 4 & & & Baik & Baik & \\
\hline 3 & Asus & Zenfone Go & 5.1 & Berhasil & Baik & Baik & $\begin{array}{l}\text { Eror pada } \\
\text { tombol di } \\
\text { menu AR }\end{array}$ \\
\hline 4 & Asus & $\begin{array}{l}\text { Zenfone } 2 \\
\text { Laser }\end{array}$ & 6.1 & Berhasil & Baik & Baik & Tidak ada \\
\hline 5 & Asus & $\begin{array}{l}\text { Zenfone Go } \\
4 \mathrm{G}\end{array}$ & 6.1 & Berhasil & Baik & Baik & Tidak ada \\
\hline 6 & Samsung & $\mathrm{J} 2$ prime & 6.1 & Berhasil & Baik & Baik & $\begin{array}{l}\text { Eror pada } \\
\text { fokus } \\
\text { kamera }\end{array}$ \\
\hline
\end{tabular}

\section{Pembahasan dan Hasil Uji Coba}

Setelah penulis melakukan pengujian terhapda aplikasi augmented reality edukasi hardware komputer berbasis android pada beberapa smartphone pada table 4.9, maka didapatkan hasil bahwa aplikasi dapat diinstal pada ke empat smartphone pada tabel dan dapat berjalan dengan baik dan terdapat beberapa eror yang terjadi pada smartphone asus zenfone go dan samsung $\mathrm{j} 2$ yaitu untuk asus zenfone go kerusakan pada tombol antarmuka yang terdapat pada menu start pada mode kamera dan untuk samsung kerusakan terjadi pada fokus kamera yang menyebabkan objek 3D tidak dapat muncul karena pendeteksian marker tidak bejalan dengan baik selebihnya berjalan dengan baik. Perbedaan dari semua smartphone yang dilakukan uji coba terdapat pada resolusi layar smartphone yang berpengaruh pada ukuran tampilan, ukuran tulisan dan kecerahan layar. Semakin besar resolusi smartphone akan semakin bagus dapat dilihat pada tabel 2 dimana untuk smartphone xiaomi note 4 memiliki tampilan layar dan kualitas gambar yang lebih baik dari smartphone lain, karena smartphone ini memiliki resolusi layar yang lebih besar yaitu 1080 x 1920 pixel dan memiliki sensor yang lengkap, untuk aplikasi augmented reality membutuhkan sensor accelerometer atau gyroscope untuk memunculkan objek 3D . Sensor-sensor ini yang memainkan peran penting dalam aplikasi augmented reality, maka untuk smartphone yang memiliki kedua buah sensor seperti xiaomi note 4 akan memiliki kualitas memunuclkan objek yang 3D lebih baik dari pada smartphone yang hanya memiliki sensor accelerometer.

Pada percobaan diatas smartphone xiaomi 4 note memiliki performa yang sangat baik karena didukung oleh resolusi dan sensor yang baik, tetapi untuk smartphone lainnya hanya memiliki performa dan tampilan yang normal.

\section{PENUTUP}

Simpulan

Secara umum penelitian ini telah sesuai dengan tujuan yang diharapkan yaitu pembuatan aplikasi edukasi hardware komputer berbasis teknologi augmented reality menggunakan android.

Berdasarkan batasan masalah dan tujuan yang dipaparkan pada penelitian ini, kemudian dikaitkan dengan hasil temuan penelitian dan pembahasannya, maka secara garis besar dapat dibuat beberapa kesimpulan sebagai berikut :

1) Aplikasi edukasi hardware komputer dengan konsep Augmented Reality dengan menggunakan metode multi marker yang dapat digunakan sebagai media pembelajaran bagi pelajar maupun masyarakat umum.

2) Aplikasi yang dibuat dapat menampilkan objek 3D sesuai dengan mengarahkan smarthpone kearah marker yang ditentukan, dengan adanya aplikasi ini maka perangkat 
smartphone berbasis Android dapat digunakan sebagai alat peraga dalam menampilkan objek hardware komputer.

3) Dengan aplikasi ini diharapkan dapat membantu memberikan informasi terkait hardware komputer bagi pelajar maupun masyarakat umum tentang.

\section{Saran}

Aplikasi edukasi hardware komputer dengan konsep Augmented Reality ini masih membutuhkan beberapa penyempurnaan yang belum dapat dilakukan oleh penulis karena keterbatasan yang dimiliki. Sebagai penyempurnaannya, maka saran yang dapat diberikan oleh penulis adalah sebagai berikut:

1. Menambahkan objek 3D hardware komputer dalam bagian perangkat masukan dan perangkat keluaran.

2. Menambahkan vidio yang berisi tentang penjelasan hardware yang sesuai dengan marker dalam menu informasi untuk melihat bentuk hardware tersebut secara nyata.

3. Menambahkan menu tutorial perakitan komputer dalam aplikasi.

4. Menambahkan fitur kuis atau pertanyaan dalam aplikasi ini, sehingga pengguna dapat melatih pengetahuan mereka tentang hardware komputer.

5. Menambahkan bahasa inggris dalam pilihan bahasa. Sehingga dapat diakses secara internasional.

\section{DAFTAR PUSTAKA}

Ambarita, A. dan Muharto. 2016. Metode penelitian sistem informasi: mengatasi kesulitan mahasiswa dalam menyusun proposal penelitian. Yogyakarta: Deepublisher.

Dhanta, Rizky. 2009. Pengantar Ilmu Komputer. Surabaya: Andi.

Haller, M. Billinghust, M. Dan Thomas, B.H. (2007).Emerging technologies of augmented reality: interface and design. Hershey: Idea Group.

Paliling, A. 2017. Katalog Penjualan Rumah Berbasis Android Menggunakan Teknologi Augmented Reality dan Virtual Reality, 16(1), 35-46.

Sagita, S., \& Amalia, R. 2014. Pembelajaran Tata Surya Menggunakan Teknologi Augmented Reality. Faktor Exacta, 7(3), 224-235.

Salbino, S.2015. Buku pintar gadget android untuk pemula. Jakarta: KunciKom

Sutarbi, Tata.2013. Komputer dan Masyarakat. Yogyakarta: Andi. 